\title{
The Effect of Customer Experience and Service Quality on Satisfaction in Increasing Loyalty
}

\author{
Endang Tjahjaningsih \\ Management Department \\ Stikubank University \\ Semarang, Indonesia \\ naning@edu.unisbank.ac.id
}

\author{
Suzy Widyasari \\ Management Department \\ Stikubank University \\ Semarang, Indonesia \\ suzy@edu.unisbank.ac.id
}

\author{
Ali Maskur \\ Management Department \\ Stikubank University \\ Semarang, Indonesia \\ maskur@edu.unisbank.ac.id
}

\author{
Lingga Kusuma \\ Postgraduate Program of Magister Management \\ Stikubank University \\ Semarang, Indonesia \\ lingga.kusuma@gmail.com
}

\begin{abstract}
Customer experience and service quality are several factors that can affect satisfaction and have the impact on loyalty. The aim of this study was to investigate whether customer experience and service quality influence satisfaction and impact loyalty or not. The sample of this study was 104 customers of PT Indonesia Comnets Plus SPBU Semarang taken by using a purposive sampling technique. The collected data were analyzed using multiple regression test. The results of this study prove that customer experience affects satisfaction; service quality affects satisfaction; and satisfaction affects loyalty. The better the customer experience in terms of what the company provided in handling disruption and ease of communication, the higher the satisfaction. The higher the satisfaction indicated by the customer subscription period according to the service subscription contract period, the higher the loyalty. Based on these findings, it can be concluded that customer experience and service quality effectively increase customer satisfaction to build customer loyalty.
\end{abstract}

Keywords: customer experience, service quality, satisfaction, loyalty

\section{INTRODUCTION}

Business competition in telecommunication sector, especially in the corporate or B2B segment, is getting tougher recently. Customer loyalty plays an important role and becomes a determining factor for company survival. Companies with loyal customers will be able to maintain and improve their performance. Customer loyalty becomes a reference point because competition is getting tighter, which makes it harder for companies to find new customers. This condition encourages telecommunication companies to always strive and be consistent in maintaining and retaining their existing customers.

PT. Indonesia Comnets Plus (ICON +) SBU Semarang is a subsidiary of PT. PLN (Persero) in the PLN Group which is engaged in telecommunication services and information technology systems. Establishment of business units in each region is to accelerate service improvement and to achieve company performance targets. From 2016 to 2018, PT. ICON + SBU Semarang is having problems maintaining customer loyalty. Customers are companies that subscribe to PT. ICON + SBU Semarang, especially from the corporate customer group or Business to Business (B2B). This grouping according to company sales rules is customers who have business entities such as limited liability companies, foundations, schools, colleges, universities, institutions, offices, centers, and local or central government. It was recorded that the average length of subscription was 800 days, but then in 2017 the quality decreased with an increase in the number of subscribers who unsubscribed by 252 subscribers, with the average length of subscription dropping to 339 days. This condition was experienced by PT. ICON + SBU Semarang although the company had made efforts to improve the quality of service by increasing the speed of time in handling disruptions and providing a number of special promos such as prices and systematic tiered capacity increases to certain customers

Customer loyalty is a deep commitment to repurchase or subscribe to a product or service consistently [1]. Customer satisfaction is one of the factors affecting loyalty; satisfied customers tend to be more loyal than dissatisfied customers. This is in line with the research by Daikh [2] and Osman [3] which proved that satisfaction has a positive effect on customer loyalty. Without their customer satisfaction, the company will be difficult to survive in the face of competitive rivalry because the customer will move on other enterprise services. In contrast, Prentice [4,5] research results explained that satisfaction is not a precondition of loyalty. Further, Powers and Choi [6] and Jimanto and Kunto [7] revealed that satisfaction did not impact loyalty. 
Several factors can affect satisfaction, including experience and service quality. Customer experience is a perceived assessment of the superiority of a product/ service [8]. The company which gives the right to the customer experience will be successful in a competitive market. Customer experience as a multidimensional concept involves the customer's cognitive, affective, emotional, social and physical responses to the company during its journey, thus giving rise to customer satisfaction [9]. This is supported by the research by Dewi and Nugroho [10], Nobar Rostamzadeh [11], Senjaya, Semuel, Dharmayanti [12] state that customer experience affects customer satisfaction. The use of experience is part of customer experience, as everything that occurs at every stage in the customer cycle before the purchase to after the purchase and may include the interactions that go beyond the product [13]. The company which gives the right to customer experience will be successful in a competitive market.

Service quality can lead to customer satisfaction when the perceived service quality equals or exceeds the expected service quality [14]. When the quality of service is good, customers are reluctant to switch services. This is supported by the research by Osman et.al [15], Kumar [16], Nafisa and Sukrisna et.al [17] which state that service quality has a positive effect on customer satisfaction. Feelings of satisfaction with good company service have a positive impact on customer satisfaction. However, the research by Hermawan et al. [18] and Adi et al. [19] disclosed that service quality does not affect satisfaction.

Based on inconsistency results of several studies above, the researchers proposed this study to investigate the effect of the influence of customer experience and service quality on satisfaction and its impact on customer loyalty of PT. ICON + SBU Semarang.

\section{METHODS}

\section{A. Research Design}

This was a confirmatory research, so, in order to test hypothesis, the researchers used multiple regression analysis. The population in this study were the companies that subscribed to ICON + services, especially from the corporate customer group or Business to Business (B2B) from 2016 to 2018 of 631 customers. The number of samples in this study was 104 customers.

The sampling method was purposive sampling, with the criteria of subscribers who had terminated their subscription in the time range between 180 and 365 days (6 months to 1 year). The determination of the age range for this subscription was chosen with the consideration that the customer had actually used the product service as needed and / or had finished the trial period also as a document the contract had been signed by both parties. During this time, the invoices have been sent, paid and recorded. The subjects in this study were the decision makers in the company's business sector, namely the General Manager, Operations Manager, Marketing / Sales Manager and other managers based on their considerations as the person who has the most role and responsibility in managing the company.

\section{B. Operational Definition}

Customer Experience is on how the company understands customer expectations for experience at each touchpoints and contacts at all levels when a business relationship is built [20]. Service quality is how far the difference between reality and customer expectations for the service received [13]. Customer satisfaction is an after-purchase evaluation in which the chosen alternative gives at least the same results or exceeds consumer expectations, while dissatisfaction arises when the results obtained do not meet consumer expectations [21]. Loyalty is a voluntary customer decision to continue subscribing to a certain brand of product or service for a long period of time [22].

\section{Data Collection Technique}

The primary data were collected by self - administered questionnaire, and was combined with manager's interview. The respondents had been asked to choose the answer of provided question (7 Likert scale). The secondary data were obtained from PT. ICON + SBU Semarang

\section{Measurements Models}

The validity test was conducted using factor analysis in which each question item would be declared valid when it meets the criteria for a KMO value> 0.5 and has a factor loading value (matrix component) $>0.4$. Furthermore, the reliability test was conducted using the Cronbach alpha method. An instrument is declared reliable when it has a Cronbach alpha value $>0.7$ [23].

\section{E. Structural Model Evaluaion}

The coefficient of determination test was conducted to measure the ability of the independent variable in explaining the dependent variable well. This was indicated by the value of $\mathrm{R} 2$ which ranges from 0 to 1 , the more $\mathrm{R} 2$ is closer to number 1 , the greater the influence of the independent variable on the dependent variable [23]. Furthermore, the $F$ test was conducted to determine the relationship between the variables in each model. When the significance value is < 0.05 , there is a simultaneous influence between the independent variable on dependent variable [23].

\section{F. Multiple Linier Regression Analysis}

Multiple linear regression analysis was used in this research to explain the effect between the independent variables and dependent variables. The equation model can be described in this formula below :

where:

$$
\begin{aligned}
\mathrm{Y} 1 & =\beta 1 \mathrm{X} 1+\beta 2 \mathrm{X} 2+\mathrm{e} \\
\mathrm{Y} 2 & =\beta 3 \mathrm{X} 3+\mathrm{e}
\end{aligned}
$$

$\mathrm{Y} 1$ = Customer satisfaction 


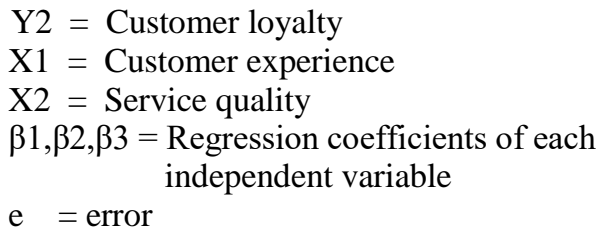

\section{$G$. The Testing of Hypothesis ( $t-$ test )}

The $t$ test is intended to see the partial effect of each independent variable on dependent variable. There are three (3) hypothesis tested in this study. By using a significance level of $5 \%$, the hypothesis is accepted when the t value is $<0.05$. This means that there is a significant effect of independent variable on dependent variable. Likewise, on the contrary, when the $\mathrm{t}$ value> than 0.05 , independent variable has no effect on dependent variable [23].

\section{H. Research Model}

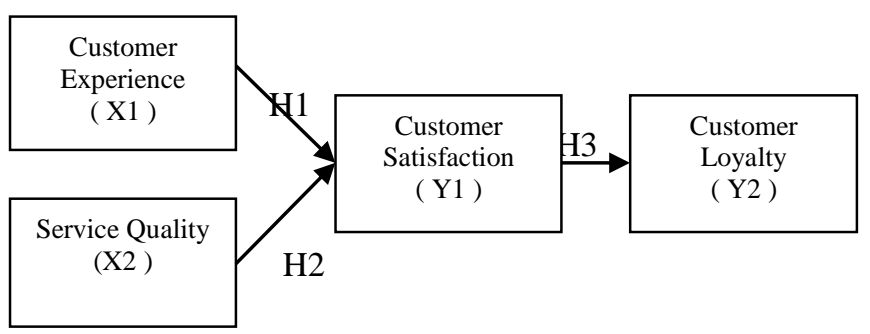

Fig 1: The Research Model

\section{III.RESULTS AND DISCUSSION}

\section{A. Respondent Profile.}

There were 104 respondents of PT ICON + SBU Semarang customers examined in this study with a subscription period of 11 months with 22 customers $(21.2 \%)$; the customers in the Central Java region were 83 customers $(79.8 \%)$, the customers from the Government segment of 40 respondents $(38.5 \%)$ and those who took a bandwidth capacity of 11-50 Mbps were 30 respondents $(28.8 \%)$.

\section{B. Validity and Reliability Test}

The validity test output shows the value of KMO and Bartlett's test from the variables of customer experience, service quality, customer satisfaction and customer loyalty > 0.5 . the existing variables have met the criteria for adequacy of the sample so that further analysis could be conducted. The loading factor value of each item for each variable has met the standard, $>0.4$. This means that each of the questions used as an instrument in this study can be declared valid.

The output reliability test results show the Cronbach Alpha value for each variable> 0.7; the variables of customer experience (X1) of 0.974 , service quality (X2) of 0.991; Customer satisfaction (Y1) of 0.956 and customer loyalty (Y2) of 0.96 . This means that these variables can be relied on to be used as the data collection instruments in this study.

\section{Regression Analysis}

Model test was applied to investigate the relationship of the variables. The Model test results are shown in Table I as follows:

Table I. REGRESSION RESULT TEST

\begin{tabular}{|c|c|c|c|c|c|}
\hline Model & $\operatorname{Adj} R^{2}$ & $F$ & B & sig & $\begin{array}{c}\text { Descripti } \\
\text { on }\end{array}$ \\
\hline \multicolumn{6}{|l|}{ Equation I } \\
\hline \multicolumn{6}{|c|}{$\mathrm{Y} 1=0,683 \mathrm{X} 1+0,534 \mathrm{X} 2+\mathrm{e}$} \\
\hline $\begin{array}{l}\text { Y1 = Customer } \\
\text { Satisfaction }\end{array}$ & $\begin{array}{l}0.86 \\
8\end{array}$ & 338,669 & 0,000 & & \\
\hline $\begin{array}{l}\text { Customer } \\
\text { experience } \\
\text { (X1) on } \\
\text { satisfaction }\end{array}$ & & & 0,683 & 0,00 & $\begin{array}{c}\text { H1 : } \\
\text { Accepted }\end{array}$ \\
\hline $\begin{array}{l}\text { Service quality } \\
\text { (X2) on } \\
\text { satisfaction }\end{array}$ & & & 0,534 & $\begin{array}{l}0,01 \\
6\end{array}$ & $\begin{array}{c}\mathrm{H} 2: \\
\text { Accepted }\end{array}$ \\
\hline \multicolumn{6}{|l|}{ Equation II } \\
\hline \multicolumn{6}{|l|}{$\mathrm{Y} 2=0,530 \mathrm{Y} 1+\mathrm{e}$} \\
\hline \multicolumn{6}{|l|}{$\begin{array}{l}\text { Y2 = customer } \\
\text { loyalty }\end{array}$} \\
\hline $\begin{array}{l}\text { satisfaction } \\
\text { (Y1) on loyalty }\end{array}$ & 0,916 & 373,062 & 0,000 & $\begin{array}{l}0,53 \\
0\end{array}$ & $\begin{array}{c}\text { H3 : } \\
\text { Accepted }\end{array}$ \\
\hline
\end{tabular}

The regression equation is $\mathrm{Y} 1=0,683 \mathrm{X} 1+0,534 \mathrm{X} 2+\mathrm{e}$. This equation shows that the customer experience variable has a dominant effect on customer satisfaction. $F=338,669$ and sign $=0,000 ;$ This means that the customer experience variable (X1) and the service quality variable (X2) together have a significant effect on the customer satisfaction variable (Y1).

The Adjusted R Square value shows the number 0.868 , this means that the ability of the variable customer experience and service quality to explain changes in the Customer Satisfaction variable is $86.8 \%$, while the remaining $13.2 \%$ is explained by other variables which are not analyzed in this research.

The regression equation is $\mathrm{Y} 2=0.530 \mathrm{Y} 1+\mathrm{e}$. This equation shows that the customer satisfaction variable has a significant positive effect on customer satisfaction. This is indicated by the large value of the beta coefficient of the customer satisfaction variable of 0.530 and the sign value. = $0.000<0.05$.

\section{The Hypothesis Testing}

1) The effect of customer experience on customer satisfaction: The result of hypothesis test 1 obtained the standardized coefficient $B$ of 0.683 and has a significant value of 0.000 lower than 0.05 . The result of the study indicates that the hypothesis 1 is accepted. It means that customer experience partially has a significant effect on customer satisfaction. This means that the better the customer 
experience in using the services of PT ICON + SBU Semarang, the higher the customer satisfaction.

2) The effect of service quality on customer satisfaction: The result of hypothesis test 2 obtained the standardized coefficient $\beta$ of 0.261 and has a significant value of 0.016 lower than 0.05 . The result of the study indicates that the hypothesis 1 is accepted. It means that of service quality partially has a significant effect on customer satisfaction. The better the quality of services provided by PT ICON + SBU Semarang, the better the customer satisfaction.

3) The effect of customer satisfaction on customer loyalty: The result of hypothesis test 3 obtained the standardized coefficient $\beta$ of 0.530 and has a significant value of 0.000 lower than 0.05 . The result of the study indicates that the hypothesis 1 is accepted. It means that customer satisfaction partially has a significant effect on customer loyalty. The better the level of customer satisfaction PT ICON + SBU Semarang, the higher the customer loyalty.

\section{IV.CONCLUSION}

In the corporate or B2B segment, customers will complain to the departments that fail to provide the products / services according to their expectations. When the company's response does not meet their expectations, customers will quickly find alternatives to other vendors. Conversely, when the company communication is fast with efficient action, the customers will be satisfied and further increase customer loyalty to the company.

Customer experience has a significant positive effect on customer satisfaction at PT ICON + SBU Semarang. The better the customer experience, the better the customer satisfaction. Customer experience is very closely related with the goal of the customer because emotional experience has a positive influence on customer satisfaction.

Service quality has a significant positive effect on customer satisfaction at PT ICON + SBU Semarang. The better the quality of company service, the higher the customer satisfaction. Feelings of pleasure for the quality of company services have a positive impact on customer satisfaction. This indicates the importance of good service quality in an effort to create customer satisfaction.

Customer satisfaction has a significant positive effect on customer loyalty at PT ICON + SBU Semarang. Satisfied customers in general also would recommend the product / service / brand to their friends / colleagues / partners. The behavior of satisfied customers with the company's performance will convey their satisfaction to others. This further emphasizes the importance of satisfaction in order to maintain customer loyalty. The higher the level of satisfaction, the higher the customer loyalty.

\section{ACKNOWLEDGMENT}

The researchers would like to say thank you for the Institution of Research and Community Service in Stikubank University who supported this research.

\section{REFERENCES}

[1] Oliver, "Whence Consumer Loyalty?", Journal of Marketing, Vol. 63, 2003: Johnson \& Wales University - Providence G

[2] Daikh, Jiana, "A Research Proposal: The Relationship between Customer Satisfaction and Consumer Loyalty", Johnson \& Wales University - Providence, JDaikh01@wildcats.jwu.edu, 2015

[3] Osman, Zahir, Mohamad, Liana and Mohamad, Ratna, “An Empirical Study of Direct Relationship of Service Quality, Customer Satisfaction and Bank Image on Customer Loyalty in Malaysian Commercial Banking Industry", American Journal of Economics 2016, 5(2): 168176.

[4] Prentice, C, "Service Quality Perceptions and Customer Loyalty in Casinos", International Journal of Contemporary Hospitality Management, 25(3), 2013a 49-64.

[5] Prentice, C, "Who Stays, Who Walks, And Why in High-Intensity Service Contexts", Journal of Business Research, 67, 2013b, 608-614.

[6] Powers, T. L., Jack, E. P., and Choi, S, "Price and Quality Value Influences on Discount Retail Customer Satisfaction and Loyalty", Journal of Consumer Satisfaction, Dissatisfaction and Complaining Behaviour, 31, 2018, 1-19.

[7] Jimanto, R.B., dan Kunto, Y.S, "Pengaruh Service Quality Terhadap Kualitas Pelanggan dengan Customer Satisfaction Sebagai Variabel Interfening Pada Ritel Bioskop The Premier Surabaya”, Jurnal Manajemen Pemasaran PETRA. 2(1). 2014,1-7.

[8] Lemke, F., Clark, M., and Wilson, H, "What Makes a Great Customer Experience', Cranfield Customer Management Forum, 2006

[9] Lemon, Katherine N and Verhoef, Peter C, "Understanding Customer Experience Throughout the Customer Journey," Journal of Marketing Sage Journals, Volume: 80 issue: 6, 2016, page(s) 69-96.

[10] Dewi, Santi Utami, Nugroho, Priyambodo Nur Ardi, "Pengaruh Customer Experience Terhadap Satisfaction dan Cusomer Loyalty", Institut Francais Indonesia di Surabaya : Jurnal Teknologi dan Terapan Bisnis (JTTB) Vol.1 No.2, 2018

[11] Nobar, Hossein dan Rostamzadeh, Reza, "The Impact Of Customer Satisfaction, Customer Experience And Customer Loyalty On Brand Power: Empirical Evidence From Hotel Industry", Journal of Business Economics and Management. 19. 417-430. 10.3846/jbem.2018.5678.

[12] Senjaya, Vivie, Semuel, Hatane, Dharmayanti , Diah, "Pengaruh Customer Experience Quality Terhadap Customer Satisfaction \& Customer Loyalty Di Kafe Excelso Tunjungan Plaza Surabaya: Perspektif B2C", Jurnal Manajemen Pemasaran Petra Vol. 1, No. 1, (2013) 1-15

[13] Venkat, R, "Impact of Customer Experience on Satisfaction, Brand Image and Loyalty: A Study in a Business-to-Business Context", Journal of Marketing, 3, 2007

[14] Parasuraman, A., Zeithaml, V. A., Berry, L. L, “A Conceptual Model of Service Quality and Its Implications for Future Research", Journal of Marketing, 1985

[15] Osman, Zahir, Mohamad, Liana and Mohamad, Ratna, “An Empirical Study of Direct Relationship of Service Quality, Customer Satisfaction and Bank Image on Customer Loyalty in Malaysian Commercial Banking Industry", American Journal of Economics 2016, 5(2): 168176.

[16] Kumar, Atul, "Effect Of Service Quality On Customer Loyalty And The Mediating Role Of Customer Satisfaction: An Empirical Investigation For The Telecom Service Industry", Journal of Management Research and Analysis, October-December, 2018;4(4):159-166 159

[17] Nafisa, Jihan dan Sukresna, I Made, "Analisis Pengaruh Layanan, Terhadap Kinerja Dan Citra Perusahaan Terhadap Loyalitas Pelanggan Melalui Kepuasan Sebagai Variabel Intervening (Studi Pada Rumah Sakit Islam Sultan Agung Semarang)", Diponegoro Journal Of Management, Vol.7 No.3, 2018,Hal.1

[18] Hermawan, B., Basalamah, S., Djameren, A., \& Plyriadi, “A Effect of Service Quality and Price Perception on Corporate Image, Customer Satisfaction and Customer Loyalty among Mobile Telecommunication 
Services Provider', IRA-International Journal of Management \& Social Sciences, 8(1), 2017, 62-73.

[19] Adi, P. H., Dhiaulhaq, M. I., \& Novandari, W. "Customer Satisfaction As The Moderating Variable of Customer Loyalty', Journal of Accounting, Management and Economics, 21(1), 2019,13-22.

[20] Hollyoake, M, "Customer Experience in B2B Environment". Retrieved September 18, 2012, frowww.springboardcs.com/articles/uploads/CxP IN_B2B.pdf

[21] Kotler, Philip., Keller, Kevin L, "Manajemen Pemasaran”, Jilid Kedua., 2015, 3 Erlangga : Jakarta.

[22] Lovelock, Christoper H. dan lauren K. Wright, "Manajemen Pemasaran Jasa, Alih Bahasa: Agus Widyantoro, 2005. Jakarta: PT. Indeks

[23] Ghozali, Imam, "Aplikasi Analisis Multivariate Dengan Program SPSS", cetakan ke 8, 2016. Semarang : Badan Penerbit UNDIP 